\title{
Effect of Different Water Sources on Survival Rate (\%) Growth Performance, Feed Utilization, Fish Yield, and Economic Evaluation on Nile Tilapia (Oreochromis niloticus) Monosex Reared in Earthen Ponds
}

\author{
Ghozlan $\mathbf{A}^{2}$, Zaki MA' ${ }^{1}$, Gaber $\mathbf{M M}^{2 *}$ and Nour $\mathbf{A}^{1}$ \\ ${ }^{1}$ Animal production Department, Alex University, Egypt \\ ${ }^{2}$ National Institutes of Oceanography and Fisheries, Egypt
}

Submission: July 19, 2017; Published: August 23, 2017

*Corresponding author: Gaber MM, National Institutes of Oceanography and Fisheries, Cairo Egypt, Email: gabermagdy@yahoo.com

\begin{abstract}
The aim of the present study was to investigate the effect of water source on survival rate \%, growth performance, feed utilization, fish yield, economic evaluation and production of Nile tilapia (Oreochromis niloticus) monosex reared in earthen ponds. Nine earthen ponds were used and divided into three categories of three earthen ponds each. The average size of each pond was approximately $5200 \mathrm{~m}^{2}, 6000 \mathrm{monosex}$ all male Nile tilapia were used in each pond and were stocked for 192 days. The fingerlings average weight was $4.38 \pm 0.03 \mathrm{~g} / \mathrm{fish}$, the fish were fed using a floating feed $25 \%$ crude protein, and were fed at a daily rate of $3 \%$ of their body weight. Results showed that body weight was increased significantly $(\mathrm{P}<0.05)$ with well water to $472.33 \mathrm{~g} / \mathrm{fish}$. While were 354.17 and $320.17 \mathrm{~g} / \mathrm{fish}$ for fresh and agricultural drainage water, respectively. Specific Growth Rates (SGR\%) increased with well water compared to both fresh and drainage water. Feed Conversion Ratio (FCR) and Protein Efficiency Ratio (PER) were improved with Agriculture drainage water. Survival rates with fresh and well water were $98.53 \%$ and $98.31 \%$ respectively, however, was $95.05 \%$ with Agriculture drainage water. Total fish yield were affected significantly by treatments. It was $2128,1921.8$, and $2837.7 \mathrm{~kg}$ at fresh, drainage and well water respectively. Net return arrived to 12996 for well water source when it was $6784 \mathrm{LE}$ for agricultural drainage water and $9158 \mathrm{LE}$ for fresh water.
\end{abstract}

Keywords: Water resources; Nile tilapia; Growth performance

\section{Introduction}

Nile tilapia, Oreochromis niloticus (Linnaeus) is one of the most important freshwater fish in world aquaculture [1]. It is widely cultured in many tropical and subtropical countries of the world [2]. Rapid growth rates, high tolerance to adverse environmental conditions, efficient feed conversion, ease of spawning, resistance to disease and good consumer acceptance make it a suitable fish for culture [3]. Farmed tilapia production increased semi dramatically in recent years, increasing from $383,654 \mathrm{mt}$ in 1990 to 2,326,413mt in 2006 [4]. Tilapia has established a secure position in a number of water impoundments of India. But, its performance in open water ponds of the country has been discouraging over the years [5]. For tilapia aquaculture is excessive reproduction and the resulting small size of the fish produced.
Egypt has suitable natural conditions for desert aquaculture. Egypt has vast resources of groundwater [6]. Fresh groundwater resources in Egypt contribute 20\% to the potential water resources in Egypt. One of the groundwater resources is the Nile Valley and Delta system with the storage capacities of 200 billionm3 and 300 billionm3, respectively. Oasis water in the west desert, Bahariya, Farafra, Dakhla, Kharga, and Siwa, were established from underground natural wells and springs.

With the prohibition of the establishment of fish farms on agricultural land, with the prohibition of the use of Nile water for fish farming, with increased competition for spaces adjacent to the lakes and sources of agricultural drainage water, despite its disadvantages, has caused the possession of new fish farm in the Nile [7]. Valley of the most difficult things and out of 
reach. Hence the search for an alternative to invade the desert, especially with the development of methods of fish farming and providing the requirements of education and with the provision of underground water of the highest purity with different salinity (fresh \& brackish \& marine) and where the trained professionals are available [8]. In the hope to produce clean fish with improved quality and cheaper than other animal proteins we conducted the present research in a private fish farm located in the desert belonging to Noubaria Agricultural Development company (Ragab Farms) aiming to study the effect of water source on survival rate (\%) growth performances, feed conversion ratio, protein efficiency ratio, annul fish yield and profitability Nile tilapia (Oreochromis niloticus) monosex commercial farming.

\section{Material and Methods}

\section{Water source}

Three types of water sources: fresh water, agricultural drainage water, and well water were compared in the present experiment. Water supplies were replaced three times during the experimental period (192 days).

\section{Experimental design}

Nine earthen ponds $\left(5200 \mathrm{~m}^{2}\right)$ were used in these experiment were divided into three categories of earthen ponds even three ponds represent one treatment (fresh water, drainage water and well water.

\section{Stocking density}

6000 monosex all male Nile tilapia (Oreochromis niloticus) fingerlings of average weight $(4.38 \pm 0.03 \mathrm{~g} / \mathrm{fish})$ were stoked in each pond on April 11, 2007 and observed through October 19, 2007. The area of each pond $5200 \mathrm{~m}^{2}$.

\section{Experimental fish}

Fingerlings of all male Nile tilapia (Oreochromis niloticus) monosex were collected from Noubaria Agricultural Development Company (Ragab Fish Hatchery) and were over wintered in earthen ponds to provide suitable fingerlings for the beginning of the growing season. All ponds in these experiment was sampled monthly using a cast net method. Sample sizes were $1 \%$ of the stocked numbers and the average individual fish weight was calculated to determine growth rates. Then, with these calculations, the feed amounts were adjusted for the following month.

\section{Experimental diet}

The floating commercial diet used in this experiment was fed at a daily rate of $3 \%$ of the fish body weight by using self feeders The ingredients of the commercial diet used in the experiment is presented in Table 1 . The dietary composition of vitamin and mineral premix is listed in. Fish were fed a floating ration for 6 days per week. Feeding rate was adjusted monthly based upon the calculated biomass of fish obtained through the monthly sampling and assumption of $100 \%$ survival.
Table 1: Composition and proximate composition of control and the experimental diets for feeding Nile tilapia.

\begin{tabular}{|c|c|}
\hline Ingredients (\%) & Diet \\
\hline Fish meal & 10 \\
\hline Meat meal & 10 \\
\hline Soybean meal & 16 \\
\hline Wheat bran & 20 \\
\hline Yellow corn meal & 38 \\
\hline Corn oil & 3 \\
\hline Bone meal & 1 \\
\hline Vitamin mixture & 1 \\
\hline Minerals mixture & 1 \\
\hline \multicolumn{2}{|c|}{ Proximate composition (\%) } \\
\hline Dry matter & 90.65 \\
\hline Crude protein & 25.12 \\
\hline Ether extract $\%$ & 5.9 \\
\hline Ash & 7.41 \\
\hline Crude fiber & 4.4 \\
\hline NFE4 & 56.17 \\
\hline Goss energykcal/g & 4.3 \\
\hline
\end{tabular}

Vit. A 8000 I.U. Vit. D3 4000 I.U;; vit. E 50mg; Vit. k3 19mg;

Vit. B1 40mg; vit. B2 25 mg; Vit. B6 125mg; vit B12 69mg;

Pantothenic acid 40mg; Nicotinic acid 125mg; Folic acid 400mg;

Biotin 20mg; cholin chloride 80mg; copper 400mg; lodine 40mg;

Iron 120mg; Manganese 220mg; Zink 22mg; Selenium 4mg

\section{Water quality}

a. Physical parameters: Water temperature ${ }^{\circ} \mathrm{C}$ was determined at every days in the experiment.

b. Chemical parameters: Samples for determination of Dissolved Oxygen (DO) were immediately fixed after sampling and DO concentration was determined according to Winkler's technique. Methods described by Golterman [9] were used in determination of ammonia. Also $\mathrm{pH}$ was measured by digital $\mathrm{pH}$ meter (Orion model $720 \mathrm{~A}, \mathrm{~s} / \mathrm{No}$ 13602) in all experiments.

\section{Chemical analysis of the commercial of diet}

Chemical analysis of the commercial diet used in the experiment was done according to [10] as shown in Table 1.

\section{Growth parameters and statistical analysis}

Data on growth, feed utilization, survival rate and proximate and chemical composition of whole fish body were subjected to 
one-way ANOVA [11]. To locate significant differences between fish size within different water resources of pond. Duncan's multiple rang test [12] was done. All percentages and ratio were transformed to arcsine values prior to analysis [13].

\section{Results and Discussion}

\section{Experimental diet}

The commercial diet used in the present experiment contained $25 \% \mathrm{CP}$ and $4.3 \mathrm{kcal} / \mathrm{g}$ gross energy (Table 1 ). Although there are large variations in the data available about the optimum protein level for tilapias which range between 20 and $40 \%$ crude protein [14-16] practical diets as low as $25 \%$ protein was successfully used for rearing monosex tilapia [3].

\section{Water quality}

Collected data on water temperature and Dissolved Oxygen (DO), $\mathrm{pH}$ and ammonia are summarized in (Tables 2-4). Water temperature throughout the present experiments ranged between $24.13 \pm 0.53$ and $30.26 \pm 0.45{ }^{\circ} \mathrm{C}$ in fresh water experiment, $24.23 \pm 0.53$ and $30.65 \pm 0.53{ }^{\circ} \mathrm{C}$ in drainage water experiment and between $29.94 \pm 0.12$ and $33.63 \pm 0.43$ in well water experiment which was the high temperature and closely related to the average of optimal value for tilapia $\left(28-30{ }^{\circ} \mathrm{C}\right)$. Our results were agreement with [17] reported that tilapia as a warm water fish that dominate African lakes, are known to grow well in high temperature. The fluctuation of water temperature are reached its maximum values during August, however its minimum were during April and November.

Table 2: Water quality parameters (Mean $\pm \mathrm{SE}$ ) of fresh water, drainage water well water during 8 months of the experimental period (April to November 2008).

\begin{tabular}{|c|c|c|c|c|c|c|c|c|}
\hline $\begin{array}{l}{ }^{*} \text { Duration } \\
\text { Months }\end{array}$ & April & May & June & July & August & September & October & November \\
\hline \multicolumn{9}{|c|}{ Fresh Water } \\
\hline $\begin{array}{c}\text { Ammonia } \\
\mathrm{mg} / \mathrm{l}\end{array}$ & $0.09 \pm 0.01$ & $0.11 \pm 0.01$ & $0.12 \pm 0.01$ & $0.12 \pm 0.01$ & $0.12 \pm 0.01$ & $0.11 \pm 0.01$ & $0.09 \pm 0.01$ & $0.12 \pm 0.01$ \\
\hline $\mathrm{Ph}$ & $7.98 \pm 0.13$ & $7.98 \pm 0.13$ & $8.00 \pm 0.13$ & $8.00 \pm 0.13$ & $8.00 \pm 0.13$ & $8.00 \pm 0.13$ & $8.00 \pm 0.13$ & $7.98 \pm 0.13$ \\
\hline $\begin{array}{c}\text { D Oxygen } \\
\text { mg/l }\end{array}$ & $6.58 \pm 0.92$ & $6.83 \pm 0.61$ & $6.82 \pm 0.56$ & $7.33 \pm 0.09$ & $7.08 \pm 0.53$ & $7.33 \pm 0.09$ & $7.37 \pm 0.09$ & $8.33 \pm 0.09$ \\
\hline Temperature & $25.4 \pm 0.12$ & $26.2 \pm 0.14$ & $28.9 \pm 0.67$ & $29.6 \pm 0.43$ & $30.3 \pm 0.45$ & $28.4 \pm 0.62$ & $26.9 \pm 0.13$ & $24.13 \pm 0.53$ \\
\hline \multicolumn{9}{|c|}{ Drainage Water } \\
\hline $\begin{array}{c}\text { Ammonia } \\
\mathrm{mg} / \mathrm{l}\end{array}$ & $0.10 \pm 0.01$ & $0.10 \pm 0.01$ & $0.11 \pm 0.01$ & $0.11 \pm 0.01$ & $0.13 \pm 0.01$ & $0.13 \pm 0.01$ & $0.12 \pm 0.01$ & $0.11 \pm 0.01$ \\
\hline $\mathrm{Ph}$ & $8.01 \pm 0.13$ & $8.03 \pm 0.13$ & $8.04 \pm 0.13$ & $8.06 \pm 0.13$ & $8.10 \pm 0.13$ & $8.09 \pm 0.13$ & $8.06 \pm 0.13$ & $8.06 \pm 0.13$ \\
\hline $\begin{array}{c}\text { D. Oxygen } \\
\mathrm{mg} / \mathrm{l}\end{array}$ & $6.56 \pm 0.90$ & $6.80 \pm 0.60$ & $6.82 \pm 0.58$ & $7.31 \pm 0.08$ & $7.07 \pm 0.52$ & $7.33 \pm 0.09$ & $7.34 \pm 0.08$ & $8.33 \pm 0.09$ \\
\hline $\begin{array}{c}\text { Temperature } \\
{ }^{\circ} \mathrm{C}\end{array}$ & $25.98 \pm 0.1$ & $26.60 \pm 0.2$ & $29.04 \pm 0.8$ & $30.29 \pm 0.4$ & $30.65 \pm 0.5$ & $28.48 \pm 0.7$ & $27.28 \pm 0.1$ & $24.23 \pm 0.5$ \\
\hline \multicolumn{9}{|c|}{ Well Water } \\
\hline $\begin{array}{c}\text { Ammonia } \\
\mathrm{mg} / \mathrm{l}\end{array}$ & $0.06 \pm 0.01$ & $0.07 \pm 0.01$ & $0.08 \pm 0.01$ & $0.08 \pm 0.01$ & $0.10 \pm 0.01$ & $0.09 \pm 0.01$ & $0.08 \pm 0.01$ & $0.06 \pm 0.01$ \\
\hline $\mathrm{Ph}$ & $8.00 \pm 0.13$ & $8.02 \pm 0.13$ & $8.04 \pm 0.13$ & $8.05 \pm 0.13$ & $8.10 \pm 0.13$ & $8.08 \pm 0.13$ & $8.04 \pm 0.13$ & $8.00 \pm 0.13$ \\
\hline $\begin{array}{c}\text { D Oxygen } \\
\mathrm{mg} / \mathrm{l}\end{array}$ & $6.07 \pm 0.52$ & $6.22 \pm 0.58$ & $6.31 \pm 0.08$ & $6.52 \pm 0.60$ & $6.56 \pm 0.90$ & $6.34 \pm 0.08$ & $6.33 \pm 0.09$ & $6.33 \pm 0.09$ \\
\hline $\begin{array}{c}\text { Temperature } \\
{ }^{\circ} \mathrm{C}\end{array}$ & $9.94 \pm 0.12$ & $30.82 \pm 0.14$ & $0.85 \pm 0.67$ & $32.46 \pm 0.4$ & $3.63 \pm 0.43$ & $33.38 \pm 0.62$ & $32.88 \pm 0.1$ & $31.63 \pm 0.53$ \\
\hline
\end{tabular}

Table 3: Effect of water source on growth performance of Nile tilapia monosex during the experimental period (days).

\begin{tabular}{|c|c|c|c|c|c|c|}
\hline \multirow{2}{*}{ Item } & \multicolumn{2}{|c|}{ Body weight (g) } & \multirow{2}{*}{ Daily gain (g) } & SGR & \multirow{2}{*}{ FCR } & PER \\
\cline { 2 - 7 } & Initial & Final & & & & \\
\hline Fresh water & $4.38 \pm 0.03$ & $354.2 \pm 14.42 \mathrm{~b}$ & $1.82 \pm 0.07 \mathrm{~b}$ & $2.27 \pm 0.02 \mathrm{~b}$ & $2.87 \pm 0.00 \mathrm{a}$ & $1.38 \pm 0.00 \mathrm{c}$ \\
\hline Drainage water & $4.35 \pm 0.08$ & $320.2 \pm 19.47 \mathrm{~b}$ & $1.64 \pm 0.10 \mathrm{~b}$ & $2.22 \pm 0.02 \mathrm{~b}$ & $2.80 \pm 0.00 \mathrm{c}$ & $1.42 \pm 0.00 \mathrm{a}$ \\
\hline Well water & $4.36 \pm 0.07$ & $472.3 \pm 2.92 \mathrm{a}$ & $2.44 \pm 0.01 \mathrm{a}$ & $2.43 \pm 0.00 \mathrm{a}$ & $2.83 \pm 0.00 \mathrm{~b}$ & $1.40 \pm 0.00 \mathrm{~b}$ \\
\hline LSD $(\mathrm{P}<0.05)^{*}$ & NS & 42.5 & 0.22 & 0.06 & 0.02 & 0.01 \\
\hline
\end{tabular}

Means in the same column having different letters are significantly different $(P<0.05)$. 
Table 4: Effect of water source, pond sizes stocking density on yield and survival rate $(\%)$ of tilapia monosex.

\begin{tabular}{|c|c|c|c|c|}
\hline \multirow{2}{*}{ Item } & \multicolumn{2}{|c|}{ Total yield } & & \multirow{2}{*}{ Survival \% } \\
\hline & Kg & $\%$ & & \\
\hline \multicolumn{5}{|c|}{ Water source } \\
\hline $\begin{array}{l}\text { a) Fresh } \\
\text { water }\end{array}$ & $2128 \pm 86.43^{b}$ & & 100 & $98.53 \pm 0.05^{\mathrm{a}}$ \\
\hline $\begin{array}{l}\text { b)Drainage } \\
\text { water }\end{array}$ & $1921.8 \pm 116.96^{\mathrm{b}}$ & & 90.31 & $95.05 \pm 0.3^{b}$ \\
\hline $\begin{array}{l}\text { c) Well } \\
\text { water }\end{array}$ & $2837.7 \pm .617^{a}$ & & 133.34 & $98.31 \pm 0.42^{\mathrm{a}}$ \\
\hline $\begin{array}{c}\text { LSD }(\mathrm{P}<0 \\
05)\end{array}$ & 255.01 & & & 0.91 \\
\hline
\end{tabular}

Means in the same column having different letters are significantly different $(P<0.05)$.

Overall means of water Dissolved Oxygen (DO) throughout the present experiment were $7.20 \pm 0.37 \mathrm{mg}$ DO/I for fresh water, $7.19 \pm 0.36 \mathrm{mg} \mathrm{DO} / \mathrm{I}$ for drainage water and $6.33 \pm 0.36 \mathrm{mg}$ DO/I for well water. The fluctuation of water Dissolved Oxygen (DO) showed that the maximum values of DO were obtained in November for the fresh and drainage water and August in well water, however, the lowest values were in April. In general, dissolved oxygen levels were within the high standards and higher than cited by Boyd [18] for good production of tilapia ( 4.20 to $5.90 \mathrm{mg} \mathrm{DO} / \mathrm{I}$ ) in aquaculture ponds. One of the most important environmental factors is dissolved oxygen. It is considered a limiting factor for success or failure in intensive culture. An excellent aquaculture attribute of tilapia is their tolerance to low dissolved oxygen concentration [8]. The dissolved oxygen content in earthen ponds depends on the pond water temperature, fish biomass and rate of water exchange [19]. Chervinski [20] reported that O.niloticus survived short term exposure to $0.1 \mathrm{mg}$ DO/ 1 . However, Collins [21] observed in a review on oxygen concentration of various studies, that growth rate of non-salmonid fish was increasingly depressed as dissolved oxygen fall below 50\% saturation. Rappaport [22] reported that growth of carp was reduced by predawn dissolved oxygen less that $25 \%$ saturation. Tichert-C \& Green [23] compared the growth of tilapia monosex in earthen ponds aerated or unaerated at 10 or $30 \%$ saturation of dissolved oxygen. They found that tilapia production and final weight were significantly greater in aerated ponds than unaerated ponds.

The water $\mathrm{pH}$ values throughout the present experiments ranged between $8.00 \pm 0.13$ and $8.10 \pm 0.13$ with an overall mean of $8.04 \pm 0.13$ in fresh water and ranged between $8.01 \pm 0.13$ and $8.10 \pm 0.13$ with an overall mean of $8.05 \pm 0.13$ in drainage water and ranged between $7.98 \pm 0.13$ and $8.01 \pm 0.13$ with an overall mean of $8.00 \pm 0.13$ in well water. The fluctuations of $\mathrm{pH}$ reach the highest value of $8.10+0.13$ during August in fresh and drainage water and $8.01+0.13$ in well water. The results showed that the present $\mathrm{pH}$ values are suitable. For rearing tilapia monosex in earthen ponds. Johnson [24] recommended the range of pH 6.5 to 9.0 for most of freshwater fish species.
The water un-ionized ammonia (NH3) throughout the present experiments ranged between $0.09 \pm 0.01$ and $0.12 \pm 0.01$ with an overall mean of $0.11 \pm 0.01 \mathrm{in}$ fresh water and ranged between $0.10 \pm 0.01$ and $0.13 \pm 0.01$ with an overall mean of $0.11 \pm 0.01$ in drainage water and ranged between $0.06 \pm 0.01$ and $0.10 \pm 0.01$ with an overall mean of $0.077 \pm 0.01$ in well water. The fluctuations of un-ionized ammonia reach the highest values of $0.13 \mathrm{mg} / \mathrm{l}$ during August. Unionized ammonia concentrations in the experimental ponds generally remained below levels which would cause chronic toxicity problems in tilapia. Tilapia is more tolerant to elevated levels of ammonia than more other sensitive species such as salmonids [24]. Some tilapias have been shown to acclimate to higher levels of ammonia after chronic exposure to low levels [25]. Johnson [24] showed that levels of un-ionized ammonia which may adversely affect growth in tilapia range from $1 \mathrm{mg} / \mathrm{l}$ to $2 \mathrm{mg} / \mathrm{l}$ ammonia where temperature and $\mathrm{pH}$ are within normal range.

\section{Growth performance of tilapia monosex}

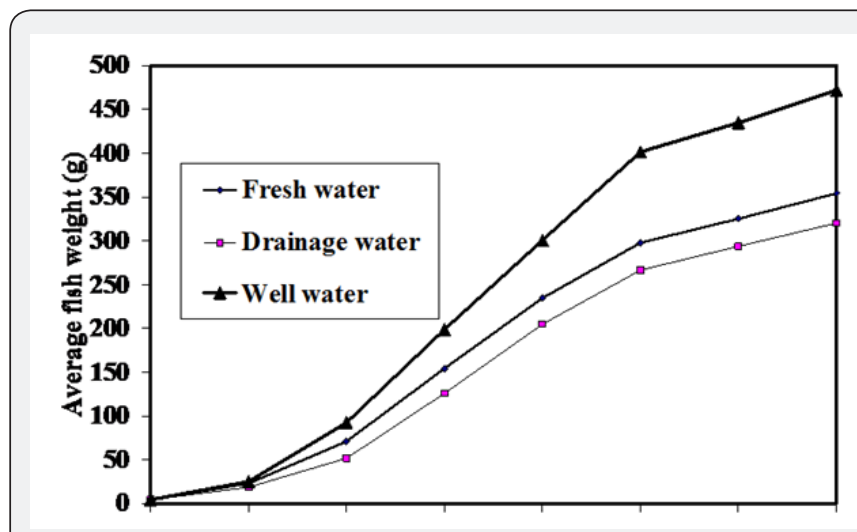

Figure 1: Effects of water source on fish growth.

Mean weight: Results of the present study showed that the mean weights at all rearing intervals different significantly $(\mathrm{P}<0.05)$ during all the experimental periods (Figure 1). Averages of fish body weights for fresh water, drainage water and well water were found to be 23.16, 18.66 and $25.16 \mathrm{~g}$, respectively after the 1st month of stocking. The statistical evaluation of results indicated that live weights at this period increased significantly $(\mathrm{P}<0.05)$ with using well water. A similar trend was also observed in fish body weights during the other growing periods. At harvest average body weight of fish stocked at well water was significantly $(\mathrm{P}<0.05)$ higher tshan that of fish stocked in fresh or drainage water, which indicates that weights fish were decreased in fresh and drainage water with increasing for used well water at harvest were $354.17 \mathrm{~g}$, $320.17 \mathrm{~g}$ and $472.33 \mathrm{~g}$ for fresh, drainage and well water, respectively. This significant advancement in fish body weights with increasing at higher temperature of water advocated by Azaza [26] reported that the final mean weight was significantly higher at 26 and 30 ${ }^{\circ} \mathrm{C}$ than at 22 and $34{ }^{\circ} \mathrm{C}$. This finding agree with our results. 


\section{Oceanography \& Fisheries Open access Journal}

Average daily gain (ADGg/day): Results presented in Table revealed that water sources, affected significantly $(\mathrm{P}<0.05)$ ADG during all experimental periods tested $(30,60,90,120,150,180$ and 210 days after start). In general these results indicated that the well water favored significantly ADG of the tilapia monosex in intensive culture system. The results of this point were in agreement with those found by [5] who grew 0 . niloticus from $49 \mathrm{~g}$ to $271 \mathrm{~g}$ in 122 days (1.4\%/day). Siddiqui [27] found that ADG of tilapia 0 . niloticus reared for 98 days at different water exchange in outdoor concrete tanks was $1.06 \mathrm{~g} /$ day at $30 \%$ dietary crude protein. In the present study the average daily gain was higher with $25 \%$ crude protein at all treatments. However, the optimal feeding rate depends on fish size and water temperature [28].

Specific growth rate (SGR\%): Results presented in Table, revealed that water sources, affected significantly $(\mathrm{P}<0.05) \mathrm{SGR} \%$ during all experimental periods tested $(30,60,90,120,150,180$ and 205 days after start). In general these results indicated that the well water, favored significantly $(\mathrm{P}<0.05) \mathrm{SGR} \%$ of the tilapia monosex in intensive culture system. During all tested experimental periods tested $(30,60,90,120,150,180$ and 205 days after start) SGR\% increased significantly $(\mathrm{P}<0.05)$ in almost linear manner in the well water than fresh and drainage water. In the present study SGR\% values in case of well water continuously higher than fresh or drainage water in all experimental periods. This may be due to the higher temperature of the well water (average $31.94{ }^{\circ} \mathrm{C}$ ) compared to 27.47 and $27.81{ }^{\circ} \mathrm{C}$ for fresh and drainage water, respectively. The results obtained in SGR\% are in agreement with those found by Eid \& El Denasoury [29] who indicated that increasing temperature from $16^{\circ} \mathrm{C}$ to $27^{\circ} \mathrm{C}$ improve growth rate of Nile tilapia, which using well water.

Feed conversion ratio (FCR): Results presented in table, show that there were significant $(\mathrm{P}<0.05)$ effects of water sources on FCR, feed conversion ratio was observed at harvest was 2.87 at fresh water, followed by 2.83 at well water and 2.80 at drainage water and 2.94 for $1700 \mathrm{~m}^{2}$ followed by 2.89 for $4000 \mathrm{~m}^{2}$ followed by 2.75 for $5200 \mathrm{~m}^{2}$ and was 2.57 for 6000 fish/acre, 2.75 for 8000 fish/acre and 2.78 for 10000 fish/ acre. The analyses of variance of the FCR values are presented in table. The FCR is affected by the physiological state of the fish, environmental condition [30]. Lovshin [31] found that FCR for all male tilapia in earthen ponds was higher (4.3) than when compared with all male and female tilapia in earthen ponds (FCR=7.2). While, fish growth is affected by the amount of feed consumed and the efficiency of assimilation [32].

Protein Efficiency Ratio (PER): Results of Protein Efficiency Ratio (PER) are presented in table, There were significant $(\mathrm{P}<0.05)$ effects of water sources, on $P E R$, it improved significantly $(\mathrm{P}<0.05)$ with each increase in pond sizes and decrease stocking density throughout the experimental periods. The best PER observed at harvest was 1.42 with drainage water, followed by 1.40 at well water and 1.38 at fresh water [33] confirmed that when protein supply is appropriate $400-500 \mathrm{~g}$ protein/kg feed for percid fish), different lipid contents in feeds do not have an impact on the rearing results of pikeperch.

Fish Survival Rate: Results in table showed that survival rates were changed significantly $(\mathrm{P}<0.05)$ by water resources, in fresh and well water were insignificantly $(\mathrm{P}<0.05)$ different but survival of the fish in drainage water was $95.05 \%$ which was less than survival rates in both fresh water and well water indicating the probable effect of some faction of water quality.

Fish Yield: Results of (Table 4) show fish yield (kg) per acre as affected by water sources. Results revealed that total yield increased significantly $(\mathrm{P}<0.05)$ with well water. The total production was found to be $133.34 \%$ and $90.31 \%$ for well water and drainage water, respectively, while it was found to be $76.33 \%$ and $68.84 \%$ for $4000 \mathrm{~m} 2$ and $5200 \mathrm{~m} 2$. The results of the present experiment were similar to those of [34] who showed that the net yield of tilapia monosex in earthen ponds was $16750 \mathrm{Kg} / \mathrm{ha}$ (7035.0kg/acre) after 100 days of stocking of $80.000 \mathrm{fish} / \mathrm{ha}$, (33600 fish/acre, 8 fish/m2) on the other hand [16] indicated that increasing temperature from $16{ }^{\circ} \mathrm{C}$ to $27{ }^{\circ} \mathrm{C}$ improved growth rate of Nile tilapia. Watanabe [35] found that growth rates generally increase with increasing temperature and where markedly lower at $22{ }^{\circ} \mathrm{C}$ and well water is the best because the temperature constant through the year and the best quality of the water. Zhang [36] found the higher yield obtained in small pond sizes because the bigger ponds with greater surface area were more difficult to manage and often resulted in lower fish yields. All fish species are characterized by an ideal range of temperature in which they show their maximum growth [37-39]. Several studies have been reported that the specific water temperature range showed the faster growth in Pikeperch, Sander lucioperca at $20^{\circ} \mathrm{C}$ to $25^{\circ} \mathrm{C}$ [ $\left.40-42\right]$. Low temperature causes sluggishness by retarding the digestion speeding of fish [43]. Some researchers have found that the digestion rate has been increased as the temperature increases [44]. Environmental temperature is one of the most important ecological factor which also influence the behavior and physiological process of aquatic animals [45]. One of the major advantages of groundwater sources is their constant temperature throughout the year. Shallow sources of groundwater approximate the mean air temperature of the area. The chemistry of groundwater is directly dependent on the geology of the area surrounding the source. In limestone areas, groundwater is hard, and high in calcium and carbon dioxide [46]. In areas of granite formation, the groundwater tends to be soft, low in dissolved minerals and carbon dioxide. As will be discussed later, there are advantages and disadvantages to both, emphasizing the need for early extensive water quality testing. Water temperature has substantial effect on fish metabolism. In response to decreasing of water temperature the enzyme activity of tissues have been increased [47]. Velmurugan [48] have investigated that histopathological and tissue enzyme changes of C. gariepinus exposed to nitrite when water temperatures changes from $27{ }^{\circ} \mathrm{C}$ to $35{ }^{\circ} \mathrm{C}$. In a stressful and unfavorable environmental condition GPT and GOT may increase in blood 
serum [49]. In the present study serum GPT and GOT level were affected by different water temperature. Serum GPT and GOT amount in different fish fed at $20{ }^{\circ} \mathrm{C}$ are comparatively lower than those of fish fed at $16{ }^{\circ} \mathrm{C}$ and $24{ }^{\circ} \mathrm{C}$ experiments (Tables 1-3). These results indicated that $20^{\circ} \mathrm{C}$ may be a favorable water temperature for better growth of $16 \mathrm{~g}$ juvenile Korean rockfish.

\section{References}

1. Coimbra AM, Reis-HMA (2005) Nile tilapia, Oreochromis niloticus L., reproduction inhibition by dietary exposure to Aroclor 1254. Bull Environ Contam Toxicol 75(2): 407-412.

2. Lin YH, Lin Shih-M, Shiau SY (2008) Dietary manganese requirements of juvenile tilapia, Oreochromis nilotis x O.aureus. Aquaculture 284(14): 207-210.

3. El-Saidy DMS, Gaber MM (2005) Effect of dietary protein source and feeding frequency on growth performance, production traits and body composition of Nile tilapia, Oreochromis niloticus (L) cultured in concrete tanks. Egyptian J Nutrition and feeds 8(1): 1077-1089.

4. Food and Agriculture Organization of the United Nations (FAO) (2007) FAO Fish Stat plus Aquaculture Production. Rome, Italy, pp: 1970-2002.

5. Jhingran AG (1991) Performance of tilapia in Indian waters and its possible impact on the native ichthyofauna. In the IPFC Proceedings, Bogor, Indonesia. FAO Fisheries Report No. 458. FAO, Rome, Italy, pp 143-161.

6. Ahmed RA, Ele-JS, Mohamed AD (2002) Desalination of brackish groundwater in Egypt. Desalination 152: 19-26.

7. El-kassas MA (1998) Freshwater Problem in Egypt in Land. In: M ElRazaz (Edt.), Water and Soil. Educational Palace General Organization Publication, Cairo, Egypt.

8. Simon L, Eren T, Jeanne N (2011) Freshwater conservation planning: the case for systematic approaches. Freshwater Biology 56(1): 6-20.

9. Golterman HL, Clymo RS, Ohnstad MAM (1978) Methods of physical and chemical analysis of fresh waters. Blackwell Scientific Publications, Oxford, USA, p. 213.

10. AOAC (2000) Official Methods of Analysis. (16 $6^{\text {th }}$ edn), Association of Official Analytical Chemists. Arlington, Virginia, USA.

11. Statistical Analysis System (1993) SAS/STAT user's guide release (6.03 edn), SAS Institute Inc. Cary, North Carolina, USA.

12. David BD (1955) Multiple Range and Multiple F Tests. Biometrics 11(1): 1-42.

13. Jerrold HZ (1984) Biostatistical Analysis. Prentice-Hall, Englewood Cliffs, New Jersey, USA, p. 718.

14. Wannigama ND, Weerakoon DEM, Muthukumarana G (1985) Cage culture of Sarotherodon niloticus in Sri Lanka: effect of stocking density and dietary crude protein levels on growth.

15. AS Fineman-K, AS Camacho (1987) The effects of supplemental feeds containing different protein: energy ratios on the growth and survival of Oreochromis niloticus (L.) in brackish water ponds. Aquaculture Research 18(2): 139-149.

16. Siddiqui AQ, MS Howlader AA, Adam (1988) Effects of dietary protein levels on growth, feed conversion and protein utilization in fry and young Nile tilapia, Oreochromis niloticus. Aquaculture magazine 70(1): 63-73.

17. Broussard MJR (1985) The basic biology of tilapia. Pioc. Texas Fish Farming. Conf, Texas A and M Univrsity, Collage Station, USA, pp. 0402.

18. Boyd CE (1979) Water quality in warmwater fish ponds. Agriculture Experiment Station, Auburn, Alabama, USA, pp. 359.
19. Hute M (1972) Textbook of fish culture breeding and cultivation of fish. Published by Edition Ch. De, Wyngaert, Brussels, 1970. Fertilization and season in two Central American Countries. Aquaculture 90: 279.

20. Chervinski J (1982) Environmental physiology of tilapias. In: Pullin, RVS, Lowe-McConnell RH (Eds.), The Biology and Culture of Tilapias. ICLARM Conference Proceedings No. 7, ICLARM, Manila, Philippines, pp. 119-128.

21. Collins G (1984) Fish growth and lethality versus dissolved oxygen. Proceeding of the 1984 Specialty Conference on Environmental Engineering, 25-27 June1984, ASCEJ, Los Angeles, CA, USA, pp. 750755.

22. Rappaport A, S Sarig, M Marek (1976) Result of Test of various Aeration Systems on the Oxygen Regime in the Genosar Experimental Ponds and growth of fish there in 1975. Bamidgeh 28(3): 35-49.

23. Teichert-CD, Green BW (1993) Tilapias yield improvement through maintenance of minimal oxygen concentrations in experimental growout ponds in Honduras. Aquaculture 118(1-2): 63-71.

24. Johnson SK (1986) Ground water: Its quality characteristics aquaculture. Proc. Texas fish farming conf., Texas A\&M University, USA.

25. Barry DR, Robert RS (1979) Acclimation to Ammonia by Tilapia aurea. Transactions of the American Fisheries Society 108(4): 383-388.

26. Azaza MS, Dhraief MS, Kraiem MM (2008) Effects of water temperature on growth and sex ratio of juvenile Nile tilapia Oreochromis niloticus (Linnaeus) reared in geothermal waters in southern Tunisia. J Therm Biol 33: 98-105.

27. Siddiqui AQ Howlader MS, Adam AE (1991) Effects of water exchange on Oreochromis niloticus (L.) growth and water quality in outdoor concrete tanks. Aquaculture 95(1): 67-74.

28. Wang N, Xu X, Kestemont P (2009) Effect of temperature and feeding frequency on growth performances, feed efficiency and body composition of pikeperch juveniles (Sander lucioperca) Aquaculture 289(1-2): 70-73.

29. Eid A, El-DM (1991) Effect of temperature, carbohydrate and Lipid on growth performance of Nile tilapia (Oreochromis niloticus). Zagazig Veterinary Journal 19(4): 882-892.

30. Hepher B, Pruginin Y (1982) Tilapia culture in ponds under controlled conditions. In: Pullin RSV, Lowe-Mc Connell RH (Eds.), The Biology and Culture of Tilapias. ICLARM Conf. Proc. 7, ICLARM, Manila, Philippines, pp. 185-203.

31. Lovshin LL, Da Silva AB, Carneiro-SA, Melo FR (1990) Effects of Oreochromis niloticus females on the growth and yield of male hybrids (O. niloticus female $\mathrm{x}$ O. hornorum male) cultured in earthen ponds. Aquaculture 88(1): 55-60.

32. Brian JB, James SD (1994) Effects of feeding frequency and handling on growth and mortality of cultured walking catfish Clarias fuscus. Journal of the World Aquaculture Society 25(2): 175-182.

33. Laetitia NW, Xueliang LX, Gersande B, Patrick K (2005) Effect of dietary protein, lipid and carbohydrate ratio on growth, feed efficiency and body composition of pikeperch Sander lucioperca fingerlings. Aquaculture Research 36(5): 486-492.

34. Tal S, I Ziv (1978) Culture of exotic fishes in Israel. Symposium on Culture of Exotic Fishes Atlanta GA, USA, $4: 1-9$.

35. Watanabe WO, Ernst DH, Chasar MP, Wickhtnd RI, Olla BL (1993) The effects of temperature and salinity on growth and feed utilization of juvenile, sex-reversed male Florida red tilapia cultured in a recirculating system. Aquaculture 112(4): 309-320.

36. Zhang FL, Zhu Y, Zhou XY (1987) Studies on the ecological effects of varying the size of fish ponds loaded with manures and feeds (AsianPacific Regional Research Center for Integrated Fish Farming, Wuxi (China)). Aquaculture magazine 60(2): 107-116. 
37. Person J, Buchet V, Vincent B, Le DH, Quemener L (2006) Effects of temperature on the growth of Pollack (Pollachius pollachius) juveniles. Aquaculture 251(2-4): 340-345.

38. Bjornsson B, Steinarsson A, Arnason T (2007) Growth model for Atlantic cod (Gadus morhua): Effects of temperature and body weight on growth rate. Aquaculture 27(1-4): 216-226.

39. Oyugi DO, Cucherousset J, Ntiba MJ, Kisia SM, Harper DM, et al. (2011) Life history traits of an equatorial common carp Cyprinus carpio population in relation to thermal influences on invasive populations. Fisheries Research 110: 92-97.

40. Molnar T, Szabo A, Szabo G, Szabo C, Hancz C (2006) Effect of different dietary fat content and fat type on the growth and body composition of intensively reared pikeperch Sander lucioperca (L.) Aquaculture Nutrition 12(3): 173-182.

41. Andras R, Istvan C (2008) Effect of feeding regime and temperature on on-growing results of pikeperch (Sander lucioperca L.). Aquac Res 39(8): 820-827.

42. Schulz C, Huber M, Ogunji J, Rennert B (2008) Effects of varying dietary protein to lipid ratios on growth performance and body composition of juvenile pike perch (Sander lucioperca). Aquaculture Nutrition 14(2): 166-173.

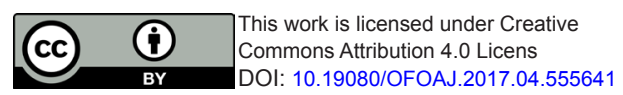

43. Bailey J, Alanara A (2006) Effect of feed portion size on growth of rainbow trout, Oncorhynchus mykiss (Walbaum) reared at different temperatures. Aquaculture 253(1-4): 728-730.

44. Turker Ali (2009) Effect of photoperiod on growth of trout (Oncorhynchus mykiss) in cold ambient sea water. Israeli journal of aquaculture-Bamidgeh 61(1): 57-62.

45. Jigang X, Xiaochen L (2010) Effect of temperature on blood parameters of the salamander Batrachupems tibetanus (Schmidt, 1925) (Amphibia: Hynobiidae) Russian Journal of Ecology 41(1): 102-106.

46. Bradley EG, Timothy RZ (1998) Exoestrogens: Mechanisms of action and strategies for identification and assessment. Environmental Toxicology and Chemistry 17(1): 3-14.

47. Hochachka PW, Somero GN (1984) Biochemical Adaptation. Princeton University Press, Princeton, New Jersey, USA, p. 525.

48. Velmurugan B, Selvanayagam M, Cengiz EI, Unlu E (2007) The effects of fenvalerate on different tissues of freshwater fish Cirrhinus mrigala. J Environ Sci Health B 42(2): 157-163.

49. Cho CY, Cowey CB, Watanabe T (1983) Finfish nutrition in Asia: methodological approaches to research and development. International Development Research Centre, Ottawa, Ontario, USA 113-117.

Your next submission with Juniper Publishers
will reach you the below assets
- Quality Editorial service
- Swift Peer Review
- Reprints availability
- E-prints Service
- Manuscript Podcast for convenient understanding
- Global attainment for your research
- Manuscript accessibility in different formats
( Pdf, E-pub, Full Text, Audio)
- Unceasing customer service
Track the below URL for one-step submission
https://juniperpublishers.com/online-submission.php

